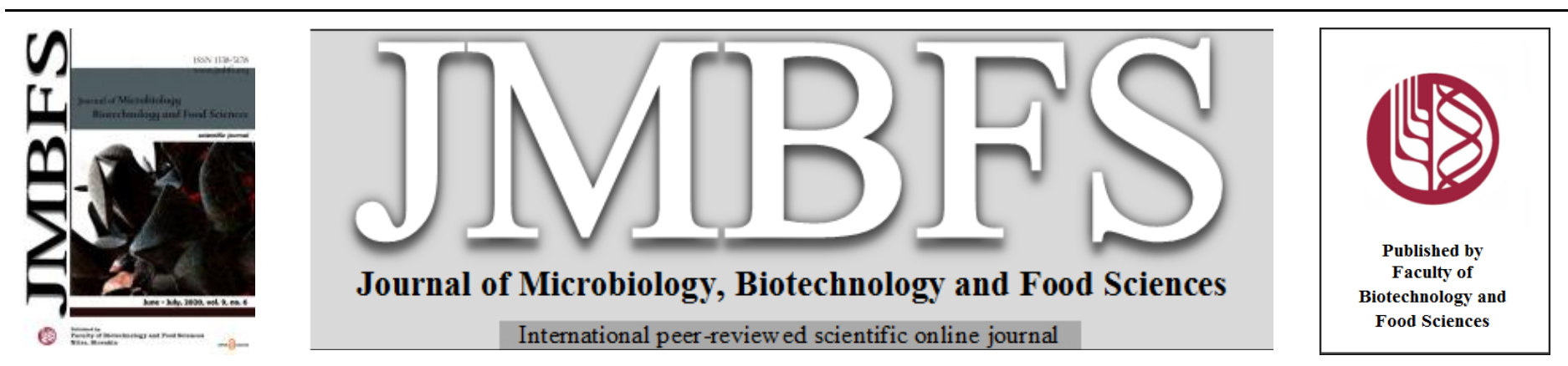

\title{
ESTIMATION OF STARCH AND SUGARS FOR DETECTION OF POTENTIAL ADULTERATION IN KAJU KATLI, A POPULAR CASHEW NUT BASED INDIAN CONFECTION
}

\author{
Rupesh Tupe and Laxmi Ananthanarayan * \\ Address(es): \\ Food Engineering and Technology Department, Institute of Chemical Technology, Nathalal Parekh Marg, Matunga, Mumbai-400019, India.
}

*Corresponding author: 1.ananthanarayan@ictmumbai.edu.in

doi: 10.15414/jmbfs.2020.9.6.1151-1156

ARTICLE INFO

Received 4. 9. 2019

Revised 24. 1. 2020

Accepted 7. 2. 2020

Published 1. 6. 2020

Regular article

open $\mathcal{O}$ access

\begin{abstract}
India has rich varieties of different confections, amongst them kaju katli is highly popular and has great commercial values. Many small and medium scale manufacturers produce kaju katli because of high consumer demand. Because of expensive ingredients, it is more prone to adulteration. This work has attempted to detect starch, sugar, lactose and skim milk powder (SMP) in kaju katli which are most easily available and cheap ingredients for adulterations or dilutions. Cashewnut (65\%), and sugar (35\%) were the optimum ingredients for kaju katli preparation as studied from sensory analysis. Further, the amount of adulterant and/or diluent in the prepared kaju katli was determined by varying the ingredients and along with adulterant and/or diluent viz. starch (5-35\%), sugar (25-50\%), lactose (5$30 \%$ ) and SMP (5-30\%), respectively. The quantification of amount of adulterant and/or diluent added and their actual value determined were determined by the correlation and regression studies. The values quantified had very strong relations with quantity added $\left(\mathrm{R}^{2}>0.99\right)$. This method will be very useful in quantifying the adulterants and/or diluents in kaju katli.
\end{abstract}

\section{INTRODUCTION}

'Traditional food' refers to a product made with specific raw materials, and/or with a recipe known for a long time, and/or using a specific process (Cayot, 2007). Sweets make an in dispensable part of the cuisine of cultures around the world and so also in India. In India, sweets also symbolize celebration, ceremony, festivity and sweetness of tongue as well as mind. When added along with sweets, dry fruits are considered to be an indication of richness of food products to which they are added and symbolize overall affluence (Ananthanarayan $\boldsymbol{e t}$ al. 2019).

In India, traditional sweets are sold by local sweet-makers called halwais on a small to retail-level scale. There are few Indian sweets mostly made with khoa which is concentrated milk such as Dharwad peda, Kesar peda, and Brown peda (Jha et al. 2014), There is very little modernization and very few companies have grown in this sector of manufacturing traditional sweets. The sector is therefore relatively unexplored due to unavailability of structured knowledge, lack of standardization, inadequate attention to food safety, improper quality control measures and use of inadequate packaging options (Baig and Balasubramaniam, 2003). Industrialization of food production, laws on food safety and even the development of innovative products makes it a necessity for the characterization of traditional food products.

Among the various popular Indian sweets, kaju katli is made by thickening fine cashew nut powder, with sugar by heating (Parmar and Sharma, 2016). The mixture is further sheeted, cut into rhomboid shapes, and then coated with silver foil (optional). It is the most favored sweet during commemorative occasions with a huge consumer appeal due to its delightful taste, mild nutty flavor, pleasant aroma, and richness of appearance (Brahmbhatt et al. 2017). Kaju katli has a great demand in Indian as well as overseas market (Sharma et al. 2017) Several flavored variants of kaju katli are available depending on additional ingredients used such as saffron, pistachio and cocoa powder.

India is a leading producer in cashewnut (Anacardium occidentale) with almost 45 different varieties in eight states with an annual production of around 817 thousand metric tons (Directorate of cashew and cocoa development, Govt. of India, www.dccd.gov.in). Total value added product made annually is 320 thousand metric tons (Small Farmers' Agri-Business Consortium, Ministry of Agriculture and Farmers Welfare, Govt. of India", www. sfacindia.com). Export value of cashewnut based products is around 27,20,982 USD with $64 \%$ of the exports aimed at the US market.
The principal ingredient used in preparation of Kaju katli is an expensive dry fruit (cashew nut), which makes it susceptible to dilution with other inferior ingredients. Milk, milk powder, sugar and starch may be potentially used as diluents with starch being reported in some samples (Mirza and Kasim, 2005) These diluents go easily with the recipe providing bulk to the sweet, resulting in higher margin of profit to manufacturers (Mirza and Kasim, 2015).

The study or manufacture of Indian traditional sweets is scientifically and industrially less explored field. There are very few established or standardized procedures available in scientific journals or in trade magazines for their preparation. The objective of this work was to establish the methodology for identification of presence of commonly used diluents in kaju katli formulation by preparing kaju katli samples with deliberate addition of the potential diluents in fixed proportions and subjecting the samples to different analytical methods for estimation of added sugars and starch. Further the robustness and accuracy of analytical methods employed for detection of added diluents was established.

\section{MATERIALS AND METHODS}

\section{Materials}

Cashewnut (Vengurla variety) and sugar (Madhur ${ }^{\mathrm{TM}}$ ) were procured from the local market of Matunga, Mumbai and used for the preparation of kaju katli. Food grade skim milk powder (SMP) (Sagar ${ }^{\mathrm{TM}}$ ), AR grade lactose (SDFCL, India) and corn starch (SDFCL, India) were used besides sugar as potential diluents in the preparation of kaju katli. Zinc acetate, phosphotungstic acid, glycine, $\mathrm{NaOH}$, methylamine- $\mathrm{HCl}$, sodium sulphite, iodine, dinitrosalicylic acid (DNSA) were procured from SDFCL, India and used for analysis.

\section{Methods}

\section{Standardization of Kaju katli preparation}

The cashewnuts and sugar were powdered in domestic grinder to get powder which passes through 80 mesh of standard sieve. The optimization of kaju katli formulation was done by uniform mixing of cashewnut powder and sugar powder in different proportions such as 75:25, 70:30, 65:35, 60:40, 55:45, 50:50 which was followed by cooking till the mixture started leaving sides of pan. The processing parameters used were: Cooking $80-90{ }^{\circ} \mathrm{C}$ for $5 \mathrm{~min}$, cooling to temperature $45-50{ }^{\circ} \mathrm{C}$ followed by compressing and sheeting. The mixtures were 
allowed to cool, sheeted on a rolling board and cut into characteristic rhomboid shaped pieces (side: $1 \mathrm{~cm}$ and thickness $0.3 \mathrm{~cm}$ ).

\section{Sensory evaluation to standardize kaju katli formulation}

Sensory analysis was conducted using a nine point hedonic scale (ranging from $1=$ dislike extremely to $9=$ like extremely) for sweetness and overall acceptability by a semi-trained panel consisting of 20 members to select the best proportion of cashewnut to sugar in the formulation.

\section{Preparation of kaju katli variants by partial replacement of cashewnut with added diluents}

The partial replacement of cashewnut ingredient in the optimized kaju katli formulation was done. Corn starch, lactose and SMP were used for replacemen of cashewnut ingredient at 5-30\% of total material used in the formulation. Sugar (sucrose) which is a part of the kaju katli formulation was varied between 25 to $50 \%$ of total material used in the formulation. The different self-diluted variants of kaju katli so generated were subjected to analysis as described below.

\section{Estimation of Starch in kaju katli}

Starch in the sample was estimated using an official method prescribed by FSSAI, India for milk and milk products with some modification ( $f$ ssai manual methods of food, 2016). One gram of kaju katli sample was added with $20 \mathrm{~mL}$ of ethanol $(80 \%)$ to curdle the kaju katli. Precipitate was filtered through a filter paper (Whatman \#1) and then washed with $80 \%$ ethanol till the precipitate was free from reducing sugars (i.e. when the washings gave a negative test with Benedict's solution for reducing sugar). Precipitate was dispersed and made to $100 \mathrm{~mL}$ with distilled water (DW) and hydrolyzed by refluxing in a boiling wate bath for $150 \mathrm{~min}$ with addition of $5 \mathrm{~mL}$ of concentrated $\mathrm{HCl}$. The solution was then cooled and neutralized with $10 \mathrm{~N} \mathrm{NaOH}$. Neutralized solution was made up to $500 \mathrm{ml}$ with DW and filtered through a filter paper $(0.45 \mu \mathrm{m})(\boldsymbol{f s s a i}$ manual methods of food, 2016). Reducing sugars was estimated in the filtrate by DNSA method (Miller, 1959). Standard curve was prepared using glucose (5002000mg).

Starch content in the sample was calculated as follows:

$$
\text { Starch }(\%)=\text { Reducing sugar }(\%) \times 0.9
$$

\section{Estimation of Sucrose in kaju katli}

Kaju katli sample (1 g) was weighed and added to $80 \%$ ethanol $(20 \mathrm{ml})$ to curdle the kaju katli. Precipitate was filtered through Whatman \#1 filter paper and residue washed with $80 \%$ ethanol till the filtrate was free from reducing sugars (i.e. when the washings gave a negative test with Benedict's solution for reducing sugar). Filtrate was concentrated by rotary evaporator (IKA, Germany) at $50{ }^{\circ} \mathrm{C}$ under vacuum to $25 \mathrm{~mL}$ to remove ethanol. To $5 \mathrm{~mL}$ of concentrated filtrate, 20 $\mathrm{mL} \mathrm{DW}$ and $3 \mathrm{~mL}$ of $6.34 \mathrm{~N} \mathrm{HCl}$ was added and mixture refluxed in boiling water bath for 20 minutes. The mixture after hydrolysis was neutralized with $10 \%$ $\mathrm{NaOH}$, cooled and made up to $100 \mathrm{~mL}$ with DW. The reducing sugars was estimated in this by DNSA method (Miller, 1959). Standard curve was prepared using glucose (500- 2000mg). Total sucrose was calculated using following formula:

Total Sucrose $=$

0.95 [Total redsucing sugars $-(1.05 \times$ redcuing sugards from lactose $)$ ]

\section{Estimation of lactose in kaju katli}

Lactose in the sample was estimated using an official method prescribed by FSSAI, India for milk based sweets ( ssai manual methods of food, 2016 and Nickerson et al., 1976). Eight gram of kaju katli sample was mixed with $1 \mathrm{~mL}$ of zinc acetate- phosphotungstic acid (ZAPT) reagent, dispersed and made to $10 \mathrm{~mL}$ with DW and after 10 min. the samples were filtered using Whatman \# 1 filter paper. To $0.5 \mathrm{~mL}$ of the filtrate, $0.5 \mathrm{~mL}$ of $1 \mathrm{~N} \mathrm{NaOH}$ solution was added, further it was diluted to $10 \mathrm{~mL}$ with DW and filtered using Whatman \# 1 filter paper. Five $\mathrm{mL}$ of this filtrate was diluted to $10 \mathrm{~mL}$. To $5 \mathrm{~mL}$ of this solution was added $5 \mathrm{~mL}$ of glycine- $\mathrm{NaOH}$ buffer $(\mathrm{pH} 12.8), 0.5 \mathrm{~mL}$ of methylamine solution and $0.5 \mathrm{~mL}$ of $1 \%$ sodium sulphite. Tubes were heated in water bath at $65{ }^{\circ} \mathrm{C}$ for 25 min and cooled immediately in an ice bath to stop the reaction. Absorbance was read against blank at $540 \mathrm{~nm}$ in a spectrophotometer (UV1800, Shimazdu Corp. Japan). Standard curve was prepared using lactose $(50-350 \mathrm{mg}$ ) and the results were expressed as lactose $\mathrm{g} / \mathrm{g}$ of sample.

\section{Estimation of SMP in kaju katli}

Milk powder is more likely to be added as a diluent than lactose which is an isolated constituent from milk available at a higher price. The major constituents of SMP are milk proteins and lactose. So the lactose content of SMP was determined by using ZAPT reagent as already described in section 2.2.6. The amount of SMP added to the kaju katli formulation was then determined based on lactose estimated in the sample using ZAPT reagent.

\section{Statistical Analysis}

All experiments were performed in triplicates and analyzed in duplicates, results are reported as mean \pm standard deviation. The data was subjected to analysis of variance (ANOVA) and Duncan multiple range tests were used to compare differences between treatments at $95 \%$ confidence level (IBM SPSS statistics 23 for windows).

\section{RESULTS AND DISCUSSION}

Kaju katli variants were prepared by using various combinations of cashewnut and sugar such as $75: 25$ to $50: 50$ in which $65: 35 \mathrm{w} / \mathrm{w}$ combination (sample C) scored highest in terms of sweetness $(7.65 \pm 0.86)$ and overall acceptability $(7.83 \pm 0.0 .88)$. As the proportion of sugar increased beyond $35 \%$ the scores for sweetness and overall acceptability decreased (Table 1) as the samples were found to be too sweet while as the proportion of cashewnut increased above $65 \%$ the scores for sweetness and overall acceptability again decreased (Table 1) as the samples were found to be less sweet (Parmar and Sharma, 2016 ).

Table 1 Sensory analysis of kaju katli variants for sweetness and overall acceptability

\begin{tabular}{lllll}
\hline No. & $\begin{array}{l}\text { Sample } \\
\text { Code }\end{array}$ & $\begin{array}{l}\text { Kaju: Sugar }(\% \\
\text { w/w })\end{array}$ & $\begin{array}{l}\text { Score for } \\
\text { sweetness }\end{array}$ & $\begin{array}{l}\text { Score for overall } \\
\text { acceptability }\end{array}$ \\
\hline 1 & A & $75: 25$ & $6.80 \pm 0.88^{\mathrm{a}, \mathrm{b}}$ & $6.58 \pm 0.88^{\mathrm{b}}$ \\
2 & B & $70: 30$ & $6.90 \pm 1.36^{\mathrm{a}, \mathrm{b}}$ & $7.30 \pm 1.36^{\mathrm{a}, \mathrm{b}}$ \\
3 & C & $65: 35$ & $7.65 \pm 0.86^{\mathrm{a}}$ & $7.83 \pm 0.86^{\mathrm{a}}$ \\
4 & $\mathrm{D}$ & $60: 40$ & $6.33 \pm 1.00^{\mathrm{b}}$ & $5.86 \pm 1.00^{\mathrm{c}}$ \\
5 & E & $55: 45$ & $6.33 \pm 1.67^{\mathrm{b}}$ & $6.25 \pm 1.67^{\mathrm{b}}$ \\
6 & F & $50: 50$ & $5.80 \pm 1.91^{\mathrm{c}}$ & $5.83 \pm 1.91^{\mathrm{c}}$ \\
\hline
\end{tabular}

All the values in the table are expressed as mean \pm standard deviation.

This optimized formulation of $65 \%$ cashewnut and $35 \%$ sugar was selected for all further studies involving addition of diluents in which the cashewnut ingredient was replaced weight by weight with the diluent. Corn starch, sucrose, lactose, and SMP were the diluents selected for this work. Analysis of starch, sucrose and lactose was performed by methods described in methods section. A correction had to be applied for all results of analysis. The value of the correction to be applied was worked out on the basis of the amount of cashewnut ingredient present in the kaju katli formulation after partial substitution by the diluent. This was based on the knowledge that pure cashewnut on analysis resulted in values for starch $(60.72 \mathrm{mg} / \mathrm{g}$ as given in Table 2), sucrose $(134.65 \mathrm{mg} / \mathrm{g}$ as given in Table 4) and lactose (i.e. reducing sugars by ZAPT) $(325.54 \mathrm{mg} / \mathrm{g}$ as given in Table 3). Cashewnut analysis has revealed that it has a starch content of 4.6 to $11.2 \%$ and sucrose content of $6.3 \%$ while it may have reducing sugars of $1-3 \%$ (Rico et al., 2015).

Table 2 Effect of replacement of cashewnut ingredient with corn starch, sucrose and lactose in varying proportions on the estimated starch content in kaju katli formulations

\begin{tabular}{|c|c|c|c|c|c|c|c|c|c|}
\hline \multirow[t]{2}{*}{ Sr. No } & \multicolumn{4}{|c|}{ Kaju katli Formulation (1 g) } & \multirow{2}{*}{$\begin{array}{l}\text { Starch content } \\
\text { on as is basis } \\
(\mathrm{mg})\end{array}$} & \multirow{2}{*}{$\begin{array}{l}\text { Moisture } \\
\text { content }(\%)\end{array}$} & \multirow{2}{*}{$\begin{array}{l}\text { Starch } \\
\text { content on } \\
\text { moisture free } \\
\text { basis } \\
(\mathrm{mg} / \mathrm{g})\end{array}$} & \multirow{2}{*}{$\begin{array}{l}\text { Correction } \\
\text { Value } \\
\text { (to be } \\
\text { subtracted) }\end{array}$} & \multirow{2}{*}{$\begin{array}{l}\text { Corrected Value of } \\
\text { starch content on } \\
\text { moisture free basis } \\
(\mathrm{mg})\end{array}$} \\
\hline & $\begin{array}{l}\text { Cashew nut } \\
(\mathrm{mg})\end{array}$ & $\begin{array}{l}\text { Corn starch } \\
(\mathrm{mg})\end{array}$ & $\begin{array}{l}\text { Sucrose } \\
(\mathrm{mg})\end{array}$ & $\begin{array}{l}\text { Lactose } \\
(\mathrm{mg})\end{array}$ & & & & & \\
\hline 1 & 1000 & 0 & 0 & 0 & $55.33 \pm 2.72$ & $9.70 \pm 0.10$ & $60.72 \pm 3.03$ & -- & -- \\
\hline 2 & 0 & 1000 & 0 & 0 & $946.73 \pm 13.01$ & $3.50 \pm 0.10$ & $\begin{array}{l}979.55 \pm \\
13.46\end{array}$ & -- & -- \\
\hline 3 & 0 & 0 & 1000 & 0 & $-4.63 \pm 0$ & $0.60 \pm 0.40$ & $-5.20 \pm 0.04$ & -- & -- \\
\hline 4 & 0 & 0 & 0 & 1000 & $-4.60 \pm 0$ & $0.00 \pm 0.10$ & $-4.61 \pm 0.01$ & -- & -- \\
\hline
\end{tabular}




\begin{tabular}{|c|c|c|c|c|c|c|c|c|c|}
\hline 5 & 350 & 300 & 350 & 0 & $295.67 \pm 3.63$ & $7.70 \pm 0.90$ & $318.42 \pm 3.13$ & 19.37 & $298.79 \pm 3.13^{\mathrm{g}}$ \\
\hline 6 & 400 & 250 & 350 & 0 & $258.53 \pm 3.97$ & $8.40 \pm 0.30$ & $280.26 \pm 5.07$ & 22.13 & $258.13 \pm 5.07^{\mathrm{f}}$ \\
\hline 7 & 450 & 200 & 350 & 0 & $202.53 \pm 9.32$ & $8.70 \pm 0.30$ & $220.14 \pm 9.63$ & 24.90 & $195.24 \pm 9.63^{\mathrm{e}}$ \\
\hline 8 & 500 & 150 & 350 & 0 & $165.07 \pm 5.14$ & $9.07 \pm 0.12$ & $180.03 \pm 5.63$ & 27.67 & $152.37 \pm 5.63^{\mathrm{d}}$ \\
\hline 9 & 550 & 100 & 350 & 0 & $116.40 \pm 3.74$ & $8.23 \pm 0.25$ & $125.98 \pm 3.76$ & 30.43 & $95.06 \pm 3.00^{\mathrm{c}}$ \\
\hline 10 & 600 & 050 & 350 & 0 & $73.93 \pm 4.92$ & $7.80 \pm 0.90$ & $80.02 \pm 5.43$ & 33.20 & $46.83 \pm 5.43^{b}$ \\
\hline $11(\mathrm{CS})$ & 650 & 0 & 350 & 0 & $32.67 \pm 0.61$ & $7.73 \pm 0.06$ & $35.19 \pm 0.66$ & 35.96 & $-0.77 \pm 0.66^{\mathrm{a}}$ \\
\hline \multicolumn{10}{|c|}{ Cashewnut ingredient replacement with sucrose } \\
\hline 12 & 500 & 0 & 500 & 0 & $31.93 \pm 1.60$ & $9.67 \pm 0.15$ & $35.02 \pm 1.72$ & 27.67 & $7.35 \pm 1.72^{\mathrm{d}}$ \\
\hline 13 & 550 & 0 & 450 & 0 & $24.93 \pm 1.53$ & $7.23 \pm 0.21$ & $26.74 \pm 1.68$ & 30.43 & $-3.69 \pm 1.68^{\mathrm{a}}$ \\
\hline 14 & 600 & 0 & 400 & 0 & $34.80 \pm 1.71$ & $9.70 \pm 0.10$ & $38.18 \pm 1.91$ & 33.20 & $4.98 \pm 1.91^{\mathrm{b}, \mathrm{c}, \mathrm{d}}$ \\
\hline $15(\mathrm{CS})$ & 650 & 0 & 350 & 0 & $34.33 \pm 1.70$ & $9.80 \pm 0.10$ & $37.70 \pm 1.83$ & 35.96 & $1.73 \pm 1.83^{\mathrm{b}}$ \\
\hline 16 & 700 & 0 & 300 & 0 & $38.87 \pm 2.23$ & $7.23 \pm 0.21$ & $41.68 \pm 2.43$ & 38.73 & $2.95 \pm 2.43^{\mathrm{b}, \mathrm{c}}$ \\
\hline 17 & 750 & 0 & 250 & 0 & $44.27 \pm 2.25$ & $8.23 \pm 0.25$ & $47.91 \pm 2.32$ & 41.50 & $6.41 \pm 2.32^{\mathrm{b}, \mathrm{d}}$ \\
\hline \multicolumn{10}{|c|}{ Cashewnut ingredient replacement with lactose } \\
\hline 18 & 350 & 0 & 350 & 300 & $29.93 \pm 1.81$ & $8.87 \pm 0.15$ & $32.59 \pm 2.02$ & 19.37 & $13.22 \pm 2.02^{\mathrm{d}}$ \\
\hline 19 & 400 & 0 & 350 & 250 & $28.00 \pm 3.75$ & $8.33 \pm 0.29$ & $30.34 \pm 4.12$ & 22.13 & $8.21 \pm 4.12^{c}$ \\
\hline 20 & 450 & 0 & 350 & 200 & $24.53 \pm 1.36$ & $8.20 \pm 0.20$ & $26.54 \pm 1.44$ & 24.90 & $1.65 \pm 1.44^{\mathrm{b}}$ \\
\hline 21 & 500 & 0 & 350 & 150 & $17.33 \pm 1.72$ & $7.90 \pm 0.72$ & $18.71 \pm 1.93$ & 27.67 & $-8.96 \pm 1.93^{a}$ \\
\hline 22 & 550 & 0 & 350 & 100 & $29.67 \pm 0.99$ & $8.43 \pm 0.06$ & $32.17 \pm 1.09$ & 30.43 & $1.74 \pm 1.09^{\mathrm{b}}$ \\
\hline 23 & 600 & 0 & 350 & 50 & $30.93 \pm 2.80$ & $7.90 \pm 0.72$ & $33.39 \pm 3.24$ & 33.20 & $-1.19 \pm 3.24^{b}$ \\
\hline $24(\mathrm{CS})$ & 650 & 0 & 350 & 0 & $32.60 \pm 1.40$ & $7.83 \pm 0.15$ & $35.15 \pm 1.48$ & 35.96 & $-0.81 \pm 1.48^{\mathrm{d}, \mathrm{b}}$ \\
\hline
\end{tabular}

Table 3 Effect of replacement of cashewnut ingredient with corn starch, sucrose and lactose in varying proportions on the estimated lactose content in kaju katli formulations

\begin{tabular}{|c|c|c|c|c|c|c|c|c|c|}
\hline \multirow[t]{2}{*}{ Sr. No } & \multicolumn{4}{|c|}{ Kaju katli Formulation } & \multirow{2}{*}{$\begin{array}{l}\text { Lactose content } \\
\text { on as is basis } \\
(\mathrm{mg})\end{array}$} & \multirow{2}{*}{$\begin{array}{l}\text { Moisture } \\
\text { content }(\%)\end{array}$} & \multirow{2}{*}{$\begin{array}{l}\text { Lactose content } \\
\text { on moisture } \\
\text { free basis }(\mathrm{mg})\end{array}$} & \multirow{2}{*}{$\begin{array}{l}\text { Correction } \\
\text { Value } \\
\text { (to be } \\
\text { subtracted) }\end{array}$} & \multirow{2}{*}{$\begin{array}{l}\text { Corrected Value of } \\
\text { lactose content on } \\
\text { moisture free basis } \\
(\mathrm{mg})\end{array}$} \\
\hline & $\begin{array}{l}\text { Cashew } \\
\text { nut } \\
\text { (mg) }\end{array}$ & $\begin{array}{l}\text { Corn starch } \\
(\mathrm{mg})\end{array}$ & $\begin{array}{l}\text { Sucrose } \\
(\mathrm{mg})\end{array}$ & $\begin{array}{l}\text { Lactose } \\
(\mathrm{mg})\end{array}$ & & & & & \\
\hline 1 & 1000 & 0 & 0 & 0 & $296.67 \pm 0$ & $9.70 \pm 0.10$ & $325.54 \pm 0.34$ & -- & -- \\
\hline 2 & 0 & 1000 & 0 & 0 & $304.44 \pm 1.92$ & $3.50 \pm 0.10$ & $315.00 \pm 1.81$ & -- & -- \\
\hline 3 & 0 & 0 & 1000 & 0 & $286.67 \pm 0$ & $0.60 \pm 0.40$ & $288.29 \pm 1.19$ & -- & -- \\
\hline 4 & 0 & 0 & 0 & 1000 & $892.22 \pm 19.53$ & $0.00 \pm 0.10$ & $893.41 \pm 19.24$ & -- & -- \\
\hline \multicolumn{10}{|c|}{ Cashewnut ingredient replacement with corn starch } \\
\hline 5 & 300 & 350 & 350 & 0 & $283.33 \pm 1.92$ & $9.13 \pm 0.55$ & $314.06 \pm 2.56$ & 361.48 & $-47.42 \pm 2.56^{\mathrm{a}}$ \\
\hline 6 & 350 & 300 & 350 & 0 & $287.78 \pm 5.09$ & $7.70 \pm 0.90$ & $307.55 \pm 4.48$ & 299.23 & $8.32 \pm 4.48^{\mathrm{b}}$ \\
\hline 7 & 400 & 250 & 350 & 0 & $288.89 \pm 0$ & $8.40 \pm 0.30$ & $310.75 \pm 0.86$ & 298.32 & $12.43 \pm 0.86^{\mathrm{b}}$ \\
\hline 8 & 450 & 200 & 350 & 0 & $291.11 \pm 1.92$ & $8.70 \pm 0.30$ & $312.82 \pm 2.87$ & 297.40 & $15.42 \pm 2.87^{\mathrm{c}, \mathrm{d}}$ \\
\hline 9 & 500 & 150 & 350 & 0 & $291.11 \pm 3.33$ & $9.07 \pm 0.12$ & $312.66 \pm 3.65$ & 296.48 & $16.17 \pm 3.65^{\mathrm{c}, \mathrm{d}}$ \\
\hline 10 & 550 & 100 & 350 & 0 & $287.78 \pm 3.85$ & $8.23 \pm 0.25$ & $311.47 \pm 2.69$ & 295.57 & $15.90 \pm 2.69^{\mathrm{c}, \mathrm{d}}$ \\
\hline 11 & 600 & 50 & 350 & 0 & $285.56 \pm 1.92$ & $7.80 \pm 0.90$ & $311.47 \pm 1.56$ & 294.65 & $16.82 \pm 1.56^{\mathrm{c}, \mathrm{d}}$ \\
\hline $12(\mathrm{CS})$ & 650 & 0 & 350 & 0 & $290.00 \pm 3.33$ & $7.73 \pm 0.06$ & $312.43 \pm 3.74$ & 293.73 & $18.69 \pm 3.74^{\mathrm{d}}$ \\
\hline \multicolumn{10}{|c|}{ Cashewnut ingredient replacement with sucrose } \\
\hline 13 & 500 & 0 & 500 & 0 & $285.56 \pm 1.92$ & $9.67 \pm 0.15$ & $313.16 \pm 2.53$ & 291.67 & $21.49 \pm 2.53^{\mathrm{b}, \mathrm{c}}$ \\
\hline 14 & 550 & 0 & 450 & 0 & $286.67 \pm 3.33$ & $7.23 \pm 0.21$ & $307.40 \pm 3.17$ & 292.90 & $14.50 \pm 3.17^{\mathrm{a}}$ \\
\hline 15 & 600 & 0 & 400 & 0 & $288.89 \pm 3.85$ & $9.70 \pm 0.10$ & $316.91 \pm 4.23$ & 293.32 & $23.60 \pm 4.23^{\mathrm{c}}$ \\
\hline $16(\mathrm{CS})$ & 650 & 0 & 350 & 0 & $287.78 \pm 3.85$ & $9.80 \pm 0.10$ & $308.59 \pm 3.98$ & 293.73 & $22.24 \pm 3.98^{b}$ \\
\hline 17 & 700 & 0 & 300 & 0 & $287.78 \pm 1.92$ & $7.23 \pm 0.21$ & $311.47 \pm 1.49$ & 294.15 & $14.44 \pm 1.49^{\mathrm{a}, \mathrm{b}}$ \\
\hline 18 & 750 & 0 & 250 & 0 & $287.78 \pm 1.92$ & $8.23 \pm 0.25$ & $322.30 \pm 2.12$ & 294.57 & $16.90 \pm 2.12^{\mathrm{a}}$ \\
\hline \multicolumn{10}{|c|}{ Cashewnut ingredient replacement with lactose } \\
\hline 19 & 350 & 0 & 350 & 300 & $466.67 \pm 3.33$ & $8.87 \pm 0.15$ & $508.05 \pm 4.33$ & 204.17 & $303.88 \pm 4.33^{\mathrm{a}}$ \\
\hline 20 & 400 & 0 & 350 & 250 & $424.44 \pm 5.09$ & $8.33 \pm 0.29$ & $459.82 \pm 6.49$ & 219.57 & $240.25 \pm 6.49^{b}$ \\
\hline 21 & 450 & 0 & 350 & 200 & $403.33 \pm 3.33$ & $8.20 \pm 0.20$ & $436.41 \pm 4.41$ & 234.40 & $202.01 \pm 4.41^{c}$ \\
\hline 22 & 500 & 0 & 350 & 150 & $373.33 \pm 8.82$ & $7.90 \pm 0.72$ & $402.81 \pm 8.74$ & 249.23 & $153.57 \pm 8.74^{\mathrm{d}}$ \\
\hline 23 & 550 & 0 & 350 & 100 & $331.11 \pm 5.09$ & $8.43 \pm 0.06$ & $359.03 \pm 5.38$ & 264.07 & $94.97 \pm 5.38^{\mathrm{e}}$ \\
\hline 24 & 600 & 0 & 350 & 50 & $305.56 \pm 3.85$ & $7.90 \pm 0.72$ & $329.68 \pm 2.11$ & 278.90 & $50.78 \pm 2.11^{\mathrm{f}}$ \\
\hline $25(\mathrm{CS})$ & 650 & 0 & 350 & 0 & $274.44 \pm 1.92$ & $7.83 \pm 0.15$ & $295.94 \pm 2.04$ & 293.73 & $2.21 \pm 2.04^{\mathrm{g}}$ \\
\hline
\end{tabular}

*CS is control kaju katli formulations of optimized composition

\section{Analysis of added starch (diluent) in kaju katli variants}

Cashewnut is about 50 times the price of corn starch and so corn starch can serve as a potential diluent for cashewnut in kaju katli formulation as it is a bland ingredient which can act as a thickening agent and can blend in the kaju katli formulation without being sensorially discernible.

For estimation of added starch (corn starch: 5 to $35 \%$ ) in the kaju katli formulations (Table 2), starch content on as is basis was firstly determined. This was then expressed as starch content on moisture free basis. The correction value (to be subtracted) was arrived at based on the starch content in the cashewnut ingredient in the formulation. For example if $1 \mathrm{~g}$ of kaju katli contains cashew $(300 \mathrm{mg})$, sucrose $(350 \mathrm{mg})$ and corn starch $(350 \mathrm{mg})$, the correction value was calculated from $30 \%$ of $1 \mathrm{~g}$ of cashew i.e. $16.60 \mathrm{mg}+35 \%$ of $1 \mathrm{~g}$ of sucrose i.e. 0 , which gave a correction factor of $16.60 \mathrm{mg}$. So, as the proportion of cashewnut ingredient in the formulation increased the correction value also increased, as seen in Table 2. No correction was required for sucrose or lactose with respect to starch analysis, as they did not give any value for starch on analysis (small negative values reported in the tables). The correction value was then subtracted from starch content on the basis of free moisture to arrive at the final corrected value of added starch on moisture free basis.
Added starch (MFB) Vs Corrected value of starch

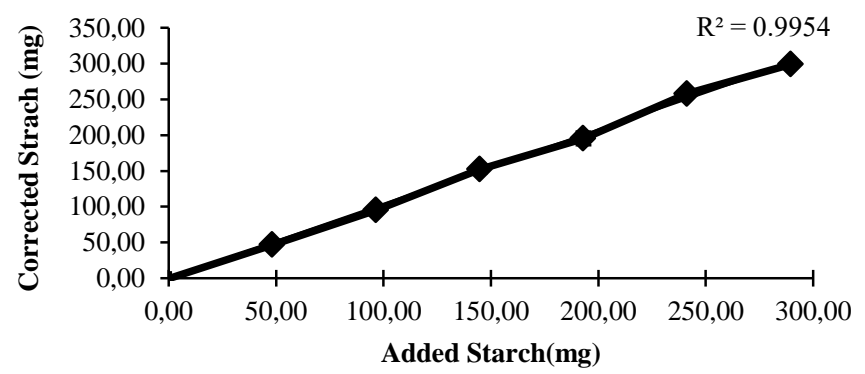

Figure 1a Correlation between added corn starch (MFB)* vs corrected value of starch 
On comparing the values of added starch (on moisture free basis) with final values obtained on analysis (Correlation plot Fig. 1a) it can be seen that with the high $\mathrm{R}^{2}$ value ( 0.9954$)$ obtained the correlation is good. Thus estimation of starch in kaju katli sample by the FSSAI method can lead us to detecting the presence of added starch in the kaju katli formulation even at relatively low levels of addition.

\section{Analysis of added lactose/ milk powder (diluent) in kaju katli variants}

In India milk is added in various sweet dishes and can be an important basic ingredient for sweets preparation. For kaju katli various recipes suggest addition of milk or milk powder because it contributes to a milky taste and softness in texture. However, addition of milk or milk powder in more quantity to replace cashewnut ingredient in kaju katli formulation can be considered a questionable practice. Cashewnut would be almost 4 times the price of SMP.
For analysis of added lactose (5-30\%) or SMP (5-30\%) in the kaju katli formulation (Tables 3 and 4 respectively) lactose content on as is basis was firstly determined using ZAPT reagent. This was then expressed as lactose content on moisture free basis. The correction value (to be subtracted) was arrived at based on the lactose value obtained by analysis in the cashewnut ingredient, in corn starch and in sucrose added in the formulation. So in this case the correction value (to be subtracted) was a total of correction value for lactose in cashewnut ingredient and correction value for lactose in corn starch/ sucrose depending on which was added as a diluent. For example if $1 \mathrm{~g}$ of kaju katli contains cashew $(350 \mathrm{mg})$, sucrose $(350 \mathrm{mg})$ and lactose $(300 \mathrm{mg})$, the correction value was calculated from $35 \%$ of cashew i.e. $103.83 \mathrm{mg}+35 \%$ of sucrose i.e. $100.33 \mathrm{mg}$ which gave a correction factor of $204.17 \mathrm{mg}$.

Table 4 Effect of replacement of cashewnut ingredient with corn starch, sucrose and SMP in varying proportions on the estimated lactose content in kaju katli formulations

\begin{tabular}{|c|c|c|c|c|c|c|c|c|c|}
\hline \multirow[t]{2}{*}{ Sr. No } & \multicolumn{4}{|c|}{ Kaju katli Formulation } & \multirow{2}{*}{$\begin{array}{l}\text { Lactose content } \\
\text { on as is basis } \\
(\mathrm{mg})\end{array}$} & \multirow{2}{*}{$\begin{array}{l}\text { Moisture } \\
\text { content }(\%)\end{array}$} & \multirow{2}{*}{$\begin{array}{l}\text { Lactose content } \\
\text { on moisture free } \\
\text { basis }(\mathrm{mg})\end{array}$} & \multirow{2}{*}{$\begin{array}{l}\text { Correction } \\
\text { Value (to be } \\
\text { subtracted) }\end{array}$} & \multirow{2}{*}{$\begin{array}{l}\text { Corrected Value of } \\
\text { lactose content on } \\
\text { moisture free basis } \\
(\mathrm{mg})\end{array}$} \\
\hline & $\begin{array}{l}\text { Cashe } \\
\text { w nut } \\
(\mathrm{mg})\end{array}$ & $\begin{array}{l}\text { Corn } \\
\text { starch } \\
(\mathrm{mg}) \\
\end{array}$ & $\begin{array}{l}\text { Sucrose } \\
(\mathrm{mg})\end{array}$ & $\begin{array}{l}\text { SMP } \\
(\text { lactose**) } \\
(\mathrm{mg})\end{array}$ & & & & & \\
\hline 1 & 1000 & 0 & 0 & 0 & $296.67 \pm 0$ & $9.70 \pm 0.10$ & $325.54 \pm 0.34$ & -- & -- \\
\hline 2 & 0 & 1000 & 0 & 0 & $304.44 \pm 1.92$ & $3.50 \pm 0.10$ & $315.00 \pm 1.81$ & -- & -- \\
\hline 3 & 0 & 0 & 1000 & 0 & $286.67 \pm 0$ & $0.60 \pm 0.40$ & $288.29 \pm 1.19$ & -- & -- \\
\hline 4 & 0 & 0 & 0 & 1000 & $528.89 \pm 5.09$ & $4.40 \pm 1.27$ & $536.64 \pm 7.69$ & -- & -- \\
\hline \multicolumn{10}{|c|}{ Cashewnut ingredient replacement with corn starch } \\
\hline 5 & 300 & 350 & 350 & 0 & $283.33 \pm 1.92$ & $9.13 \pm 0.55$ & $314.06 \pm 2.56$ & 295.89 & $18.17 \pm 2.56^{\mathrm{a}}$ \\
\hline 6 & 350 & 300 & 350 & 0 & $287.78 \pm 5.09$ & $7.70 \pm 0.90$ & $309.95 \pm 6.77$ & 295.50 & $14.45 \pm 6.77^{\mathrm{a}}$ \\
\hline 7 & 400 & 250 & 350 & 0 & $288.89 \pm 1.92$ & $8.40 \pm 0.30$ & $313.16 \pm 2.26$ & 295.11 & $18.04 \pm 2.26^{\mathrm{a}}$ \\
\hline 8 & 450 & 200 & 350 & 0 & $288.89 \pm 1.92$ & $8.70 \pm 0.30$ & $314.03 \pm 2.87$ & 294.72 & $19.30 \pm 2.87^{\mathrm{a}}$ \\
\hline 9 & 500 & 150 & 350 & 0 & $286.67 \pm 0$ & $9.07 \pm 0.12$ & $312.66 \pm 0.33$ & 294.33 & $18.32 \pm 0.33^{\mathrm{a}}$ \\
\hline 10 & 550 & 100 & 350 & 0 & $287.78 \pm 3.85$ & $8.23 \pm 0.25$ & $311.47 \pm 3.52$ & 293.94 & $17.52 \pm 3.52^{\mathrm{a}}$ \\
\hline 11 & 600 & 050 & 350 & 0 & $287.78 \pm 1.92$ & $7.80 \pm 0.90$ & $311.47 \pm 1.56$ & 293.56 & $17.91 \pm 1.56^{\mathrm{a}}$ \\
\hline $12(\mathrm{CS})$ & 650 & 0 & 350 & 0 & $286.67 \pm 3.33$ & $7.73 \pm 0.06$ & $308.84 \pm 3.59$ & 293.17 & $15.67 \pm 3.59^{\mathrm{a}}$ \\
\hline \multicolumn{10}{|c|}{ Cashewnut ingredient replacement with sucrose } \\
\hline 13 & 500 & 0 & 500 & 0 & $286.67 \pm 3.33$ & $9.67 \pm 0.15$ & $314.38 \pm 3.82$ & 291.67 & $22.71 \pm 3.82^{b, c, d}$ \\
\hline 14 & 550 & 0 & 450 & 0 & $287.78 \pm 1.92$ & $7.23 \pm 0.21$ & $308.59 \pm 1.49$ & 292.17 & $16.42 \pm 1.49^{\mathrm{a}, \mathrm{b}}$ \\
\hline 15 & 600 & 0 & 400 & 0 & $290.00 \pm 5.77$ & $9.70 \pm 0.10$ & $318.13 \pm 6.58$ & 292.67 & $25.47 \pm 6.58^{\mathrm{c}, \mathrm{d}}$ \\
\hline $16(\mathrm{CS})$ & 650 & 0 & 350 & 0 & $292.22 \pm 1.92$ & $9.80 \pm 0.10$ & $320.86 \pm 2.13$ & 293.17 & $27.69 \pm 2.13^{d}$ \\
\hline 17 & 700 & 0 & 300 & 0 & $286.67 \pm 3.33$ & $7.23 \pm 0.21$ & $307.40 \pm 3.00$ & 293.67 & $13.73 \pm 3.00^{\mathrm{a}}$ \\
\hline 18 & 750 & 0 & 250 & 0 & $290.00 \pm 3.33$ & $8.23 \pm 0.25$ & $313.87 \pm 2.88$ & 294.17 & $19.70 \pm 2.88^{\mathrm{a}, \mathrm{b}, \mathrm{c}}$ \\
\hline \multicolumn{10}{|c|}{ Cashewnut ingredient replacement with SMP } \\
\hline 19 & 350 & 0 & 350 & $300(160.80)$ & $342.22 \pm 1.92$ & $8.40 \pm 0.26$ & $370.97 \pm 2.76$ & 204.17 & $166.80 \pm 2.76^{\mathrm{a}}$ \\
\hline 20 & 400 & 0 & 350 & $250(134.00)$ & $327.78 \pm 5.09$ & $8.63 \pm 0.51$ & $356.08 \pm 5.94$ & 219.00 & $137.08 \pm 5.94^{b}$ \\
\hline 21 & 450 & 0 & 350 & $200(107.20)$ & $322.22 \pm 3.85$ & $8.20 \pm 0.20$ & $348.64 \pm 3.62$ & 233.83 & $114.81 \pm 3.62^{\mathrm{c}}$ \\
\hline 22 & 500 & 0 & 350 & $150(80.40)$ & $305.56 \pm 3.85$ & $7.90 \pm 0.72$ & $329.71 \pm 5.95$ & 248.67 & $81.04 \pm 5.95^{\mathrm{d}}$ \\
\hline 23 & 550 & 0 & 350 & $100(53.60)$ & $296.67 \pm 3.33$ & $8.24 \pm 0.37$ & $318.68 \pm 2.72$ & 263.50 & $55.18 \pm 2.72^{\mathrm{e}}$ \\
\hline 24 & 600 & 0 & 350 & $50(26.80)$ & $285.56 \pm 3.85$ & $8.63 \pm 0.23$ & $310.21 \pm 3.89$ & 278.33 & $31.87 \pm 3.89^{f}$ \\
\hline $25(\mathrm{CS})$ & 650 & 0 & 350 & $0(0)$ & $275.56 \pm 1.92$ & $7.87 \pm 0.71$ & $297.24 \pm 3.96$ & 293.17 & $4.07 \pm 3.96^{\mathrm{g}}$ \\
\hline
\end{tabular}

*CS is control kaju katli formulations of optimized composition

** Lactose content of SMP is $53.64 \%$

As the kaju katli formulation changed in composition the correction value also changed as seen in Tables 4 and 5. The correction value was then subtracted from lactose content on moisture free basis to arrive at the corrected value of lactose on moisture free basis.

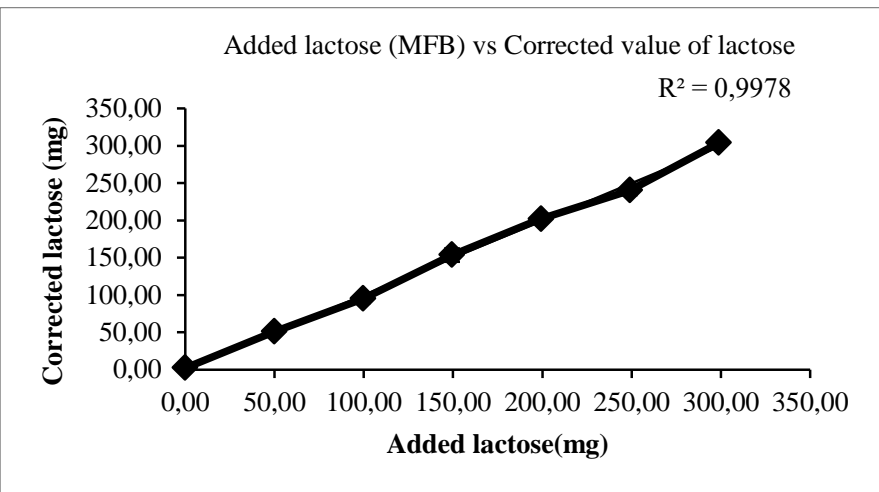

Figure 1b Correlation between added Lactose (MFB) vs corrected value of lactose
On comparing the values of added lactose/SMP (on moisture free basis) with final values obtained on analysis (Correlation plot Fig. 1b and 1c) it can be seen that with the high $\mathrm{R}^{2}$ values $(0.9978 / 0.9973)$ obtained the correlation is good Thus estimation of lactose in kaju katli sample by the FSSAI method can lead us to detecting the presence of added lactose/ SMP in the kaju katli formulation.

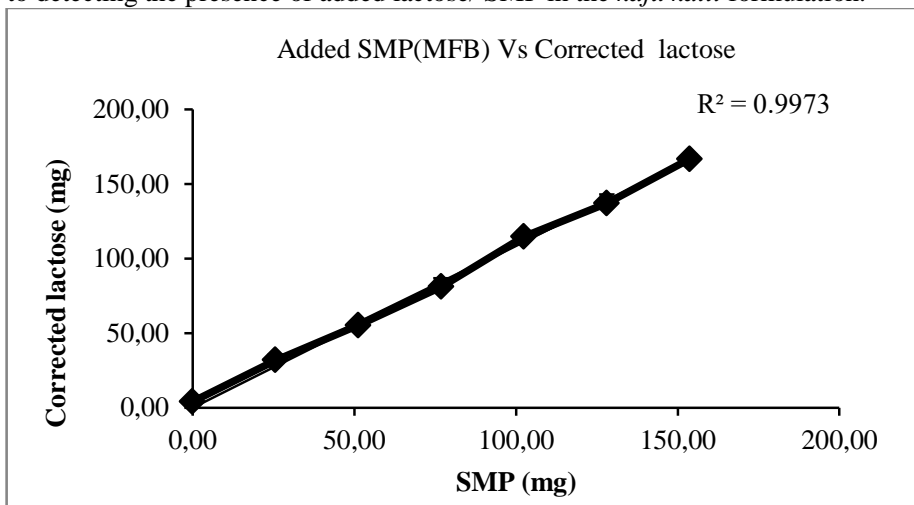

Figure 1c Correlation between added SMP (MFB) vs corrected value of Lactose 
high $\mathrm{R}^{2}$ value ( 0.997$)$ obtained the correlation is good. Thus estimation of sucrose in kaju katli sample by estimating TRS after hydrolysis can lead us to detecting the presence of added excessive sucrose in the kaju katli formulation when sucrose is intended to be used not only as a sweetener but also as a diluent.

\section{CONCLUSION}

The study has standardized the kaju katli formulation based on sensory evaluation showing a greater preference for formulation prepared by using cashew powder $(65 \%)$ and sugar $(35 \%)$. The study has demonstrated the detection of potential diluents such as starch, sucrose, lactose or milk powder in kaju katli formulations by using relatively simple chemical analytical methods. Since this is a high priced Indian sweet of great commercial value and demand this study offers a significant opportunity to ensure the quality of this product and prevent its adulteration. Compliance with food standards regulation can also be more effectively implemented.

Acknowledgment: Authors are thankful to UGC-RGNF for providing funding and Food Engineering \& Technology Department of Institute of Chemical Technology for providing the facilities for research work.

Conflict of interest: The authors report no conflict of interest.

\section{REFERENCES}

Ananthanarayan, L., Dubey, K. K., Muley, A. B., \& Singhal, R.S. (2019). Indian traditional foods: Preparation, processing and nutrition. In Traditional Foods (pp. 127-199). Springer, Cham. https://doi.org/10.1007/978-3-030-24620-4 6

Biag M. S., \& Balasubramaniam, D. (2003). Cashew nut processing in India Beverage and Food World, 30(9), 66-68.

Brahmbhatt, J., Sharma, A.K. \& Pandey, H. (2017). Standardization of grinding and cooking parameters for kajukatli production. Jamshedpur Research Review, II(XX), 36-43.

Cayot N. (2007). Sensory quality of traditional foods. Food Chemistry, 101(2),154-162. https://doi.org/10.1016/j.foodchem.2006.10.016

FSSAI manual of methods of analysis of foods Milk and milk products (2015) Food safety and standards authority of India, Ministry of health and family welfare, Government of India, New Delhi.

Jha, A., Kumar, A., Jain P., Om H., Singh R \& Bunkar D. S. (2014). Physicochemical and sensory changes during the storage of lal peda. Journal of food science technology, 51(6):1173-1178. https://doi.org/10.1007/s13197-012-0613$\underline{3}$

https://www.zauba.com/exportanalysis-KAJU+KATLI-report.html (Accessed on: July 17, 2019)

http://sfacindia.com/UploadFile/Statistics/Status\%20of\%20Cashew\%20Processin g\%20Industry\%20in\%20India-new.pdf).

July 17, 2019 retrieved from https://dccd.gov.in/Content.aspx?mid=1075\&tid=1 (Assessed on: July 17, 2019)

Miller, G. L. (1959). Use of dinitrosalicylic acid reagent for determination of reducing sugar. Analytical Chemistry, 31(3), 1959, 426-428. https://doi.org/10.1021/ac60147a030

Mirza, S. K. \& Kasim, S. S. 2015. Qualitative analysis of colour additives and adulterants in festival sweets. International Journal of Innovative Research in Science, Engineering and Technology, 4(11), 11361-11365. doi: https://doi.org/10.15680/IJIRSET.2015.0411095

Nickerson, T.A., Vujicic T.A. \& Lin A.Y. (1976). Colorimetric estimation of lactose and its hydrolytic products. Journal of Dairy Science 59(3), 386-390. https://doi.org/10.3168/jds.S0022-0302(76)84217-8

Parmar, A. F. \& Sharma, A. K. (2016). A study on commercial kajukatli preparations and standardization. Agric international 3(2): 61-68

Rico, R., Bulló, M. \& Salas-Salvad, J. (2015). Nutritional composition of raw fresh cashew (Anacardium occidentale L.) kernels from different origin. Food Science and Nutrition, 4(2), 329-338. doi: https://doi.org/10.1002/fsn3.294

Sharma, A. K., Brahmbhatt, J.V \& Patel, A. M. (2017). Storage study of standardized Kajukatli. International Journal for Scientific Research \& Development, 3(5), 406-409. 